\title{
Review \\ The Role of Gamma Oscillations in the Pathophysiology of Substance Use Disorders
}

\author{
Jessica U. Ramlakhan ${ }^{1}$, Ming Ma ${ }^{1}$, Reza Zomorrodi ${ }^{1}$, Daniel M. Blumberger ${ }^{1,2,3}$, Yoshihiro Noda ${ }^{4} \mathbb{D}$ \\ and Mera S. Barr 1,2,3,*
}

1 Temerty Centre for Therapeutic Brain Intervention, Division of Mood and Anxiety, Centre for Addiction and Mental Health, Toronto, ON M6J1H4, Canada; jessica.ramlakhan@gmail.com (J.U.R.); mingdonna.ma@mail.utoronto.ca (M.M.); Reza.Zomorrodi@camh.ca (R.Z.); Daniel.Blumberger@camh.ca (D.M.B.)

2 Institute of Medical Science, Faculty of Medicine, University of Toronto, Toronto, ON M5S1A8, Canada

3 Department of Psychiatry, Temerty Faculty of Medicine, University of Toronto, Toronto, ON M5S1A8, Canada

4 Multidisciplinary Translational Research Lab, Department of Neuropsychiatry, Keio University School of Medicine, Tokyo 160-8582, Japan; yoshi-tms@keio.jp

* Correspondence: Mera.Barr@gmail.com; Tel.: +416-535-8501 (ext. 33095)

Citation: Ramlakhan, J.U.; Ma, M.; Zomorrodi, R.; Blumberger, D.M.; Noda, Y.; Barr, M.S. The Role of Gamma Oscillations in the Pathophysiology of Substance Use Disorders. J. Pers. Med. 2021, 11, 17. https://dx.doi.org/10.3390/ jpm11010017

Received: 10 November 2020 Accepted: 24 December 2020 Published: 28 December 2020

Publisher's Note: MDPI stays neutral with regard to jurisdictional claims in published maps and institutional affiliations.

Copyright: () 2020 by the authors. Licensee MDPI, Basel, Switzerland. This article is an open access article distributed under the terms and conditions of the Creative Commons Attribution (CC BY) license (https: / creativecommons.org/ licenses/by/4.0/).

\begin{abstract}
Substance use disorders (SUDs) are a major public health problem-with over 200 million people reporting drug use in 2016. Electroencephalography (EEG) is a powerful tool that can provide insights into the impact of SUDs on cognition. Specifically, modulated gamma activity may provide an index of the pathophysiology of SUDs. Thus, the purpose of this review was to investigate the impact of alcohol, tobacco, cannabis, cocaine, and amphetamine on gamma activity, among pre-clinical and clinical populations during acute and chronic exposure and withdrawal states. We searched multiple databases for key terms related to SUDs, EEG, and gamma and ensured rigorous methods by using a standardized review reporting tool. We included 30 studies in this review and found that all substances were associated with modulation of gamma activity, across states and in both preclinical and clinical populations. Gamma oscillations appeared to be differentially modulated in clinical versus preclinical populations and had the most complex relationship with alcohol, indicating that it may act differently than other substances. The findings of this review offer insights into the pathophysiology of SUDs, providing a potential window into novel treatments for SUDs via modulation of gamma activity.
\end{abstract}

Keywords: gamma oscillations; alcohol; tobacco; cannabis; cognition; co-morbidity

\section{Introduction}

Substance abuse represents a rapidly growing global public health concern. According to the United Nations Office on Drugs and Crime, 271 million people used at least one illicit drug in 2016 [1], of which 35 million have developed substance use disorders (SUDs) [1]. Approximately 2.3 billion people self-reported as current drinkers in 2016 [2], more than 1 billion people around the world smoked tobacco in 2019 [3] and 188 million people used cannabis in 2017 [1]. Furthermore, 35 million people worldwide have SUDs but less than $15 \%$ receive treatment [1].

Cognition has been shown to be modulated with acute and chronic substance use. For example, studies have found that working memory, the ability to maintain and manipulate information over short periods of time [4], has been impaired with alcohol and cannabis use disorders (AUDs and CUDs) [5,6]. Chronic alcohol use may cause pathological changes in the brain, such as ventricle enlargement [7] and reductions in grey and white matter volume [8,9], which have been linked to cognitive impairment [8]. Cognitive deficits have also been reported in individuals following acute alcohol intoxication, including disruptions in memory [10], divided attention [11], and information processing [12]. In 
addition, chronic non-psychiatric cannabis and cocaine users have demonstrated impaired learning [13,14], memory [14-17], attention [13,15,16,18], and executive function [19]. Interestingly, cognition has been shown to rebound with discontinuing substance use (e.g., cannabis [20]), thereby furthering support for the association between cognition and SUDs, possibly through shared pathophysiology [21]. Investigating different states (e.g., acute, chronic, and withdrawal) of substance use on such pathophysiology may help to optimize the treatment for SUDs and associated cognitive deficits.

Electroencephalography (EEG) is a powerful non-invasive neurophysiological imaging technique with high temporal resolution that can measure cortical neural activity through recording from scalp electrodes [22]. There are five conventional EEG frequency bands-delta $(1-3.5 \mathrm{~Hz})$, theta $(4-7 \mathrm{~Hz})$, alpha $(8-12 \mathrm{~Hz})$, beta $(12-28 \mathrm{~Hz})$, and gamma (30-120 Hz). Gamma oscillatory activity has been associated with higher-order perceptual and cognitive processes, including long-term memory [23], selective attention [24,25], visual search [26,27], learning [28], and working memory [29-31]. In fact, increases in gamma power have been associated with increases in working memory load in healthy subjects [29,30,32] and epileptic patients [31]. Patients with schizophrenia, however, lack this ability to modulate gamma activity [30,32]. Gamma oscillations therefore may provide a window into ongoing sensory-cognitive processes in the brain.

Gamma activity has been recorded in multiple brain regions, including the hippocampus [33], neocortex [34-37], entorhinal cortex [38], olfactory bulb [39], and amygdala [40]. Gamma-aminobutyric acid (GABA) is an inhibitory neurotransmitter present in large quantities in the mammalian brain. Networks of specialized GABAergic interneurons (in particular, basket and chandelier cells; [41]) and pyramidal cells are responsible for generating a large-scale gamma oscillatory activity [42,43]. Two types of GABAergic receptors- $\mathrm{GABA}_{\mathrm{A}}$ and $\mathrm{GABA}_{\mathrm{B}}$ receptors-are linked to the generation [43-45] and modulation [43] of gamma oscillations, respectively. Gamma activity can also be produced through activation of several other receptors [45], including the metabotropic glutamate receptor [43], the muscarinic-cholinergic receptor [46], and the kainate receptor [47]. The $\mathrm{N}$-methyl-D-aspartic acid (NMDA) receptor has also been shown to influence gamma activity [48]. Given that gamma oscillations underlie several cognitive domains and are altered by substance use, deficits in gamma band activity may be a valuable index of the pathophysiology of SUDs.

The goal of this paper is to provide a comprehensive review of the existing body of literature on the effects of alcohol, tobacco, cannabis, cocaine, and amphetamine use on gamma oscillatory activity, among preclinical and clinical populations during acute, chronic, and withdrawal states.

\section{Methods}

A comprehensive literature search was conducted using the databases PubMed, MEDLINE, and PsycINFO on 3 September 2019 with no date restrictions. Search terms included "cannabi*”, "marijuana", "THC" (tetra-hydrocannabinol), "delta-9-tetra-hydrocannabinol", "alcohol", "ethanol", "EtOH", "nicotine", "tobacco", "cigarette", "cocaine", "amphetamine", and "methamphetamine" with "EEG", "electroencephalography", "gamma oscillat", "gamma activity", or "gamma power". Both relevant preclinical and clinical studies published in English were included. Studies were excluded if they investigated populations with psychiatric disorders other than alcohol, cannabis, tobacco, amphetamine, or cocaine use disorder; or schizophrenia. Studies were excluded if publication types were nonempirical research studies, editorials, opinion articles, protocols, abstracts, proceedings, conceptual analyses, case studies, patient resources, or reviews. Reference lists of reviews were manually searched for additional studies. The search produced 524 studies, and a total of 30 articles were included in the review. We complied with the Preferred Reporting Items for Systematic Reviews and Meta-Analyses (PRISMA) guideline, to ensure rigour (Figure 1) [49]. Given that oscillations in the gamma frequency are tightly linked to cognition, and that cognition is altered following substance use, gamma oscillations serves as a 
useful neurophysiological index for examining the underlying pathophysiology of SUDs for the development of novel treatment options.
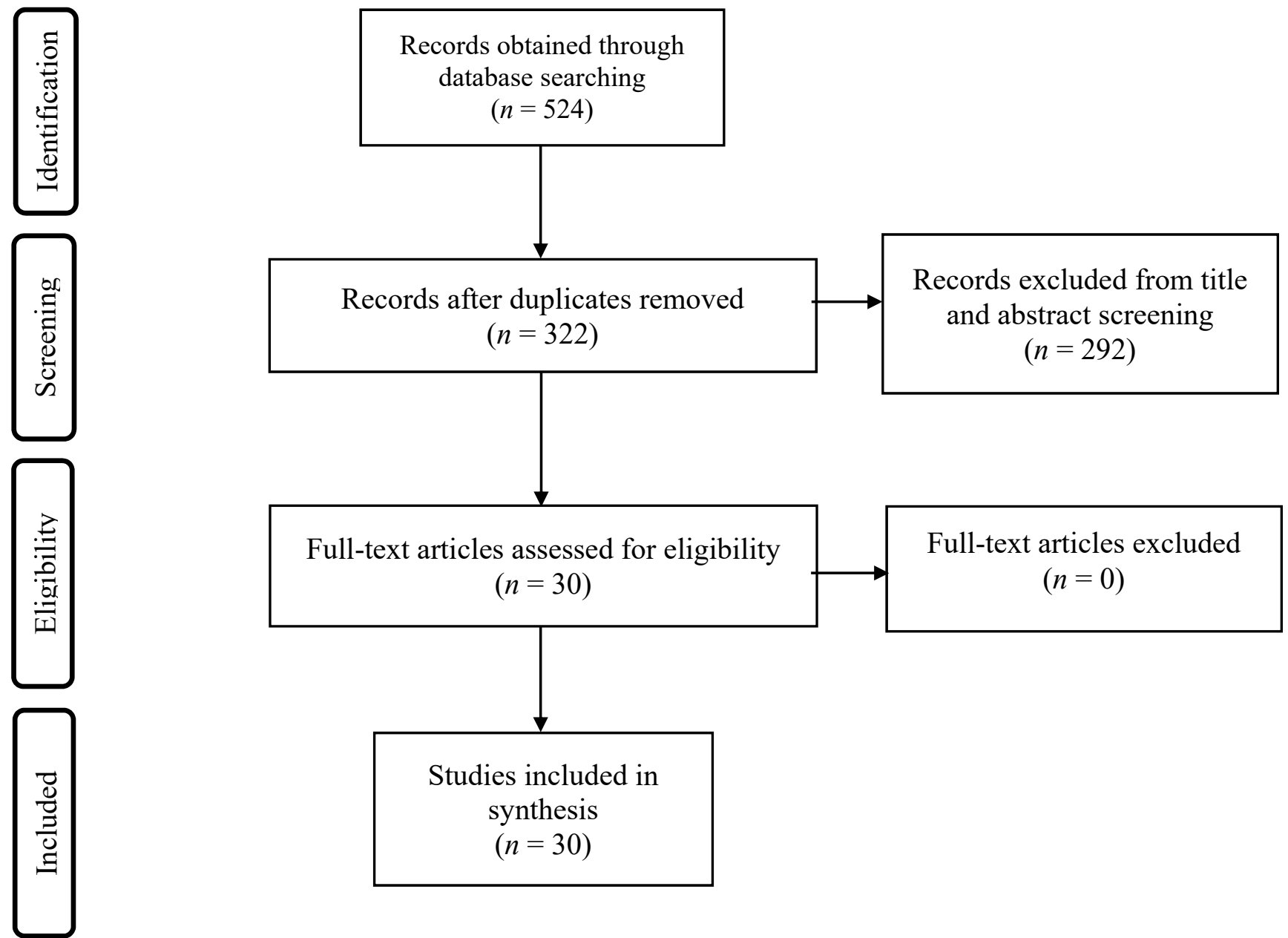

Figure 1. PRISMA flow diagram of the screening process.

\section{Results}

\subsection{Preclinical Studies}

Alcohol: There are a limited number of studies that examined gamma oscillatory activity following acute ethanol exposure (Table 1). Wang et al. reported a dose-dependent relationship between acute ethanol exposure and gamma activity in the rat hippocampal CA3 area [50]. At a low dose $(10 \mathrm{mM})$, a minor increase in gamma power was observed. However, at higher doses (25-100 mM), alcohol significantly suppressed gamma activity, with the greatest reduction occurring at $100 \mathrm{mM}(52.9 \pm 8.5 \%)$. Peak gamma frequency was not altered with exposure [50]. In another study, Tsurugizawa and colleagues investigated the effects of alcohol on local field potential (LFP) oscillations in the nucleus accumbens of 34 male Wistar rats [51]. The animals were injected intraperitoneally with $0.4 \mathrm{~g} / \mathrm{kg}$ of ethanol solution. Following ethanol exposure, alpha and beta power decreased while gamma power increased significantly [51]. 
Table 1. Preclinical Studies Examining the Effects of Alcohol on Gamma Oscillations.

\begin{tabular}{llll}
\hline Study & $\begin{array}{l}\text { Gamma Frequency } \\
\text { Range and Type }\end{array}$ & Subject Information & $\begin{array}{l}\text { Method of } \\
\text { Administration }\end{array}$ \\
\hline & & & \\
& & 38 Wistar rats & $\begin{array}{l}\text { 28-day continuous } \\
\text { exposure to } \\
\text { ethanol vapour } \\
\left(22-28 \mathrm{mg} / \mathrm{L} \mathrm{O}_{2}\right)\end{array}$ \\
\hline $\begin{array}{l}\text { Ehlers and Chaplin } \\
(1991)\end{array}$ & $32-64 \mathrm{~Hz}$ & &
\end{tabular}

\section{Main Findings}

Increased power in all frequency bands except $1-2 \mathrm{~Hz}$ and $16-32 \mathrm{~Hz}$ in the cortex $24 \mathrm{~h}$ after ethanol exposure.

No differences in gamma power in both the cortex and dorsal hippocampus 10-30 min and 2 weeks following ethanol exposure.

Increased parietal gamma and beta $(16-32 \mathrm{~Hz})$ power in

136 Male

Slawecki et al. (2006) $32-50 \mathrm{~Hz}$ Sprague-Dawley rats (adolescents: 28-30 days; adults: 60-70 days) 14-day (12 h/day) continuous exposure to ethanol vapour (95\% ethanol) adolescent rats during acute ethanol withdrawal (7-10 h post-exposure) on days 8 and 12 . No change in frontal gamma power during withdrawal in both adolescent and adult rats.

Ethanol-containing modified liquid diet at steadily increasing concentrations for 28 days

16 Social drinkers (8 males, 8 females; mean age: 25.9 years) with average weekly alcohol consumption of $191.2 \mathrm{~g}$ for males and $132 \mathrm{~g}$ for females

$\begin{array}{ll}\text { Campbell et al. } & \text { 30-80 Hz; } \\ \text { (2014) } & \text { Induced }\end{array}$

34 Male,

Tsurugizawa et al. $\quad 60-80 \mathrm{~Hz}$; (2016) alcohol-naïve Wistar rats (8-12 weeks)
$40 \%(v / v)$ alcohol solution or placebo (males consumed $0.8 \mathrm{~g} / \mathrm{kg}$, females consumed $0.72 \mathrm{~g} / \mathrm{kg}$ )

Intraperitoneal injection of $0.4 \mathrm{~g} / \mathrm{kg}$ of ethanol solution
Increased frontal and parietal gamma power during acute ethanol withdrawal (1-8 $\mathrm{h}$ after ethanol exposure).

Increased peak gamma power in the visual and motor cortices. Decreased peak gamma frequency in the visual cortex.

No change in peak gamma frequency in the motor cortex.

Increased gamma power that peaks within 5 min after ethanol injection and returns to baseline at around $10 \mathrm{~min}$ post-injection.

No change in gamma power after $5 \mathrm{mM}$ ethanol application. Increased gamma power after $10 \mathrm{mM}$ ethanol application. Decreased gamma power following 25-100 mM ethanol application (dose-dependent). No change in peak gamma frequency following ethanol exposure.

Several studies to date have examined the effects of ethanol withdrawal on the EEG spectral profiles of mice and rats (Table 1). Ehlers and Chaplin found significant elevations in cortical EEG power across almost all frequency bands, including gamma, $24 \mathrm{~h}$ following termination of prolonged ethanol exposure [52]. This was also observed in a study by Slawecki et al., investigating the withdrawal responses of male adolescent and adult rats [53]. Following ethanol vapour exposure for 14 consecutive days, prepulse inhibition increased in both groups. Although changes in frontal gamma power were insignificant, beta and gamma power in the parietal cortex significantly increased in adolescent rats during withdrawal [53]. In addition to increases in parietal gamma power, Cheaha and colleagues also found enhanced gamma activity in the frontal region, as well 
as increased locomotor activity and decreased sleep time in mice experiencing ethanol withdrawal [54]. These preclinical studies demonstrate that ethanol withdrawal is associated with increased gamma band activity, indicating central nervous system hyperexcitability during withdrawal states.

Tobacco: Several animal studies have reported dose-dependent relationships between acute nicotine exposure and gamma band activity (Table 2). Phillips and colleagues administered nicotine $(1.0 \mathrm{mg} / \mathrm{kg})$, mecamylamine $(2.0 \mathrm{mg} / \mathrm{kg})$, saline, or nicotine combined with mecamylamine in 11 male mice [55]. It was found that nicotine significantly increased auditory evoked gamma power. Moreover, pretreatment with the nicotinic antagonist mecamylamine prevented this nicotine-induced increase [55]. Song et al. also reported an enhancement in gamma activity in the rat hippocampal slices following nicotine infusion under high doses [56]. In this study, administering $10 \mu \mathrm{M}$ of nicotine did not significantly influence tetanically-induced gamma oscillations under both threshold stimulation intensity and double threshold stimulation intensity [56]. However, nicotine infusion at $100 \mu \mathrm{M}$ significantly increased both tetanic gamma power and frequency [56]. Interestingly, a recent study found a significant increase in the amplitude of kainate-induced gamma activity after just $1 \mu \mathrm{M}$ of nicotine application [57]. Furthermore, in a study conducted by Wang et al., nicotine at lower doses $(0.1-10 \mu \mathrm{M})$ increased gamma power and slightly reduced peak gamma frequency [58]. The greatest increase in gamma power $(83 \pm 21 \%)$ was also achieved after $1 \mu \mathrm{M}$ of nicotine application. However, contrary to Song et al.'s findings, Wang and colleagues reported that nicotine decreased gamma power at $100 \mu \mathrm{M}[56,58]$.

Table 2. Preclinical Studies Examining the Effects of Tobacco on Gamma Oscillations.

\begin{tabular}{|c|c|c|c|c|}
\hline Study & $\begin{array}{l}\text { Gamma Frequency } \\
\text { Range and Type }\end{array}$ & Subject Information & Method of Administration & Main Findings \\
\hline
\end{tabular}

Song et al.

(2005)
$30-80 \mathrm{~Hz}$;

Induced

(tetanic stimulation)
Wistar rats

(17-30 days)
(-) Nicotine dissolved in artificial cerebrospinal fluid
No change in gamma power after $10 \mu \mathrm{M}$ of nicotine perfusion at both threshold and double threshold stimulation intensity. Increased gamma power and frequency after nicotine perfusion of $100 \mu \mathrm{M}$ at both stimulation intensities.
Intraperitoneal injection of $0.1 \mathrm{~mL}$ of nicotine hydrogen tartrate salt $(1.0 \mathrm{mg} / \mathrm{kg})$ dissolved in saline $(0.09 \%)$
Increased gamma power following nicotine administration. mice (10-12 weeks)
Akkurt et al.
30-80 Hz;
(2010)
Sprague-Dawley rats (23-36 days)
$100 \mu \mathrm{M}(-)$ Nicotine dissolved in artificial cerebrospinal fluid

- Decreased gamma oscillation complexity during nicotine exposure.

- Decreased gamma oscillation complexity during nicotine washout.
- Increased gamma power following $1 \mu \mathrm{M}$ of nicotine administration versus control.

- Increased gamma power during nicotine washout versus control. 
Table 2. Cont.

\begin{tabular}{|c|c|c|c|c|}
\hline Study & $\begin{array}{l}\text { Gamma Frequency } \\
\text { Range and Type }\end{array}$ & Subject Information & Method of Administration & Main Findings \\
\hline $\begin{array}{l}\text { Wang et al. } \\
\text { (2015) }\end{array}$ & $\begin{array}{l}20-60 \mathrm{~Hz} ; \\
\text { Induced (kainate) }\end{array}$ & $\begin{array}{l}\text { Male Wistar rats } \\
(4-5 \text { weeks })\end{array}$ & $\begin{array}{l}0.1-100 \mu \mathrm{M} \text { nicotine sulfate } \\
\text { dissolved in artificial } \\
\text { cerebrospinal fluid }\end{array}$ & 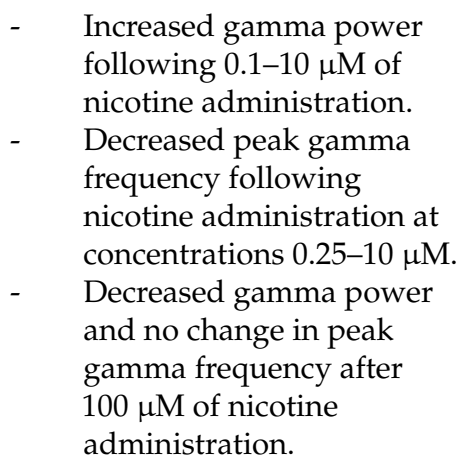 \\
\hline $\begin{array}{l}\text { Bueno-Junior } \\
\text { et al. (2017) }\end{array}$ & $\begin{array}{l}40-130 \mathrm{~Hz} \\
\text { (low gamma: } \\
\text { 40-60 Hz; high } \\
\text { gamma: } 60-130 \mathrm{~Hz} \text { ) }\end{array}$ & $\begin{array}{l}\text { Male Long-Evans rats } \\
\text { (85-90 days) }\end{array}$ & $\begin{array}{l}\text { Daily intraperitoneal } \\
\text { injection of } 0.2 \mathrm{mg} / \mathrm{kg} \text { of } \\
\text { nicotine solution (dissolved } \\
\text { nicotine hydrogen tartrate } \\
\text { salt in saline) on days } 1-5, \\
\text { followed by a } 9 \text {-day washout, } \\
\text { and a final nicotine injection } \\
\text { after washout. }\end{array}$ & 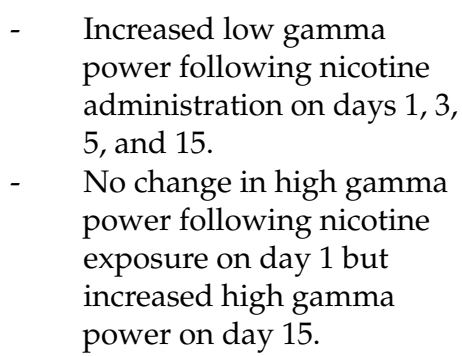 \\
\hline
\end{tabular}

One study explored the effects of acute nicotine exposure $(100 \mu \mathrm{M})$ on the complexity of gamma oscillations in the mouse hippocampus ([59] Table 2). It was found that nicotine reduced gamma oscillation complexity compared to the control and washout conditions, indicating increased synchronization of hippocampal networks.

Recently, Bueno-Junior and colleagues examined the effects of acute versus chronic nicotine exposure on brain oscillatory activity in rats [60]. The authors implemented a daily dosing regimen of nicotine $(0.2 \mathrm{mg} / \mathrm{kg})$ in vivo and found that acute nicotine administration slightly increased gamma power and reduced theta and beta power. Daily nicotine exposure produced stronger and more robust gamma activity [60]. In the following experiment, a separate group of rats was treated with nicotine following the same daily dosing regimen. Nicotine-treated rats performed significantly better in a visual attention task compared to controls, verifying the cognitive enhancing effects of nicotine [60]. In sum, nicotine administration increases gamma band activity. According to most preclinical studies, this increase in gamma power can be achieved with doses as low as $0.1 \mu \mathrm{M}$.

Cannabis: Studies have shown that chronic exposure to THC-9 in adolescent rodents induces long-lasting deficits in neural oscillations during adulthood (Table 3). For example, Raver and colleagues [61,62] showed that repeated exposure to THC in adolescents, but not adults, suppresses pharmacologically evoked cortical oscillations and impairs working memory performance in adulthood. In vitro recording of local field potentials show reduced oscillatory activity across all frequencies, whereas in vivo electrocorticogram measured specific reductions in alpha and gamma oscillations. The areas with the most pronounced deficits in gamma oscillatory activity in adulthood are also regions that were least mature during THC exposure. These preclinical findings provide insight into how adolescent cannabis use may affect gamma oscillations in adulthood, potentially as a precursor of CUDs. Overall, preclinical studies demonstrate that cannabis exposure is associated with reduced gamma activity. 
Table 3. Preclinical Studies Examining the Effects of Cannabis on Gamma Oscillations.

\begin{tabular}{|c|c|c|c|c|}
\hline Study & $\begin{array}{l}\text { Gamma Frequency } \\
\text { Range and Type }\end{array}$ & $\begin{array}{l}\text { Subject } \\
\text { Information }\end{array}$ & Method of Administration & Main Findings \\
\hline Raver et al. 2013 & $\begin{array}{l}\text { Gamma } 30-80 \mathrm{~Hz} \\
\text { (Local Field } \\
\text { Potentials and Power) }\end{array}$ & Male CD-1 Mice & $\begin{array}{l}\text { THC }(5 \mathrm{mg} / \mathrm{kg}) \text { dissolved in } \\
100 \% \text { ethanol and injected in a } \\
\text { 1:1:18 solution of ethanol castor } \\
\text { oil: } 0.9 \% \text { saline }(1 \mathrm{~mL} / \mathrm{kg})\end{array}$ & $\begin{array}{l}\text { Cannabis exposure } \\
\text { suppresses evoked cortical } \\
\text { oscillations (with marked } \\
\text { reductions in gamma and } \\
\text { alpha) and impairs working } \\
\text { memory in adolescent but } \\
\text { not adult mice. }\end{array}$ \\
\hline
\end{tabular}

CB1R/CBR2 agonist WIN55, 212-2 (1 or $2 \mathrm{mg} / \mathrm{kg}), \mathrm{CB} 1 \mathrm{R}$ inverse agonist/antagonist $\operatorname{AM} 251(0.3,0.5,1$ or $2 \mathrm{mg} / \mathrm{kg})$, CB1R/CB2R agonist (THC 5

Gamma 30-80 Hz

Raver et al. 2014 (Local Field Potentials and Power)
Male CD-1 Mice $\mathrm{mg} / \mathrm{kg}$ ) and putative CB1R-inactive enantiomer (WIN55, 212-3) dissolved in $100 \%$ ethanol and administered in a 1:1:18 solution of ethanol: $0.9 \%$ saline at final volume of $1 \mathrm{~mL} / \mathrm{kg}$
THC selectively suppresses oscillations in the medial prefrontal cortex mediated by CB1R and non-cannabinoid receptors.

Cocaine: Studies examining the effects of cocaine use on gamma oscillation are limited (Table 4). In a preclinical acute administration study, Dilgen and colleagues examined the effects of acute cocaine exposure on prefrontal cortex optogenetically evoked gamma oscillation in PV-Cre knock-in mice [63]. The results showed that acute cocaine administration resulted in a decrease in the spread of induced gamma oscillations, likely due to more synchronous principal neuron firing. The authors suggest that the increase in synchrony coupled with an increase in the entrainment of gamma oscillations may be a potential mechanism in which cocaine increases alertness in novice users.

Table 4. Preclinical Studies Examining the Effects of Cocaine on Gamma Oscillations.

\begin{tabular}{lllll}
\hline Study & $\begin{array}{l}\text { Gamma Frequency } \\
\text { Range and Type }\end{array}$ & Subject Information & $\begin{array}{l}\text { Method of } \\
\text { Administration }\end{array}$ & Main Findings \\
\hline Dilgen et al. 2013 & $\begin{array}{l}\text { Relative and peak } \\
\text { power (1-100 Hz) }\end{array}$ & $\begin{array}{l}\text { Male PV-Cre Mice (B6; } \\
\text { 129P2-Pvalb) }\end{array}$ & $\begin{array}{l}\text { Infusion (cocaine HCL, } \\
\text { SCH } 2339015 \mathrm{mg} / \mathrm{kg})\end{array}$ & $\begin{array}{l}\text { Acute cocaine administration } \\
\text { increased the entrainment of } \\
\text { gamma oscillations to the } \\
\text { optogentically induced } \\
\text { driving frequency. }\end{array}$ \\
\hline
\end{tabular}

Amphetamines: Studies investigating the role of amphetamines in neural oscillations are limited to rodent populations (Table 5). Janetsian and colleagues induced methamphetamine sensitization in rats as assessed temporal and recognition memory after 1 or 30 days of abstinence as well as recorded oscillatory activity in the medial prefrontal cortex [64]. Results showed that temporal memory was impaired after both 1 day and 30 days abstinence, while recognition memory was only impaired after 1 day of abstinence. Methamphetamine injections significantly decreased neuronal firing rates and pharmacologically induced slow gamma oscillations in both sensitized and control rats. Moreover, the number of neurons phase-locked gamma oscillations were reduced in methamphetamine sensitized rats compared to controls. Given that previous studies have demonstrated that gamma band activity is elevated during recognition tasks in both humans and rats, it has been suggested that deficits in memory following repeated methamphetamine exposure may be a result of altered gamma band activity [64]. A study by Morra and colleagues investigated the role of cannabinoid (CB) 1 receptor in methamphetamine-induced rodent 
stereotypies and disrupted gamma oscillations [65]. Prior to methamphetamine sensitization, rats were treated with either $\mathrm{CB} 1$ receptor antagonist rimonabant $(0.3 \mathrm{mg} / \mathrm{kg})$ or vehicle as control. Methamphetamine administration in control rats significantly increased high-frequency gamma oscillation power $(70-94 \mathrm{~Hz}, \sim 80 \mathrm{~Hz}$ peak) in the nucleus accumbens. Interestingly, the methamphetamine mediated increase in high-frequency gamma oscillations was attenuated by CB1 receptor blockades in rimonabant treated rats. This finding suggests that $\mathrm{CB} 1$ receptor activity is implicated in the mechanism in which methamphetamines alter local gamma oscillations. Furthermore, motor stereotypy behaviours induced by methamphetamine were also diminished in CB1 antagonist treated rats, in line with previous findings that both CB1 KO mice and local CB1 receptor antagonist injections in Nucleus accumbens reduce amphetamine-induced stereotypies. Taken together, these studies provide evidence that acute methamphetamine administration disrupts normal gamma oscillation and that its ability to do so may be modulated by CB1 activity.

Table 5. Preclinical Studies Examining the Effects of Amphetamine on Gamma Oscillations.

\begin{tabular}{|c|c|c|c|c|}
\hline Study & $\begin{array}{l}\text { Gamma Frequency } \\
\text { Range and Type }\end{array}$ & Subject Information & $\begin{array}{l}\text { Method of } \\
\text { Administration }\end{array}$ & Main Findings \\
\hline $\begin{array}{l}\text { Janetsian } \\
\text { et al. } 2015\end{array}$ & $\begin{array}{l}\text { Gamma power } \\
(30-50 \mathrm{~Hz})\end{array}$ & $\begin{array}{l}\text { Male adult } \\
\text { Sprague-Dawley rats }\end{array}$ & $\begin{array}{l}5.0 \mathrm{mg} / \mathrm{kg} \text { of } \\
\text { methamphetamine }\end{array}$ & $\begin{array}{l}\text { Temporal memory was impaired after } \\
1 \text { and } 30 \text { days of abstinence. } \\
\text { Injection of MA decreased neuronal } \\
\text { firing rate and anesthesia-induced } \\
\text { slow oscillation in both sensitized and } \\
\text { control rats. } \\
\text { Relationships were found between } \\
\text { anesthesia-induced slow oscillation } \\
\text { and gamma power. } \\
\text { Decreased number of neurons } \\
\text { phase-locked gamma frequency was } \\
\text { observed in the sensitized rats. }\end{array}$ \\
\hline $\begin{array}{l}\text { Morra } \\
\text { et al. } 2012\end{array}$ & $\begin{array}{l}\text { Oscillatory Power } \\
0-100 \mathrm{~Hz})\end{array}$ & $\begin{array}{l}\text { Male adult } \\
\text { Sprague-Dawley rats } \\
n=10\end{array}$ & $\begin{array}{l}\text { Intravenous CB1 receptor } \\
\text { antagonist rimonabant }(0.3 \\
\mathrm{mg} / \mathrm{kg}) \text { or vehicle } \\
\text { followed by an ascending } \\
\text { dose regimen of } \\
\text { methamphetamine }(0.01, \\
0.1,1 \text { and } 3 \mathrm{mg} / \mathrm{kg})\end{array}$ & $\begin{array}{l}\text { Methamphetamine increased high } \\
\text { frequency gamma oscillations } \\
(\sim 80 \mathrm{~Hz}) \text {. } \\
\text { Methamphetamine induced both } \\
\text { stereotypy and high frequency gamma } \\
\text { power that was later disrupted with } \\
\text { CB1R blockade. }\end{array}$ \\
\hline
\end{tabular}

\subsection{Clinical Studies}

Alcohol: Two studies have examined gamma band activity following acute alcohol consumption in human subjects (Table 6). In an early study conducted by Jaaskelainen and colleagues, alcohol $(10 \%(v / v))$ administered at moderate doses $(0.50 \mathrm{~g} / \mathrm{kg}$ and $0.75 \mathrm{~g} / \mathrm{kg})$ significantly reduced gamma power [66]. In this randomized and double-blind study, 10 healthy young adults with a negative family history for alcoholism participated in a dichotic listening task after consuming $0.25,0.50$, or $0.75 \mathrm{~g} / \mathrm{kg}$ of $10 \%$ alcohol beverage or placebo. The effect of alcohol on gamma power was insignificant at $0.25 \mathrm{~g} / \mathrm{kg}$, but doses 0.50 and $0.75 \mathrm{~g} / \mathrm{kg}$ markedly suppressed gamma power in both the attended and non-attended task conditions, suggesting that blood alcohol concentrations of around $0.05 \%$ already begin to influence gamma activity in healthy humans [66]. However, Campbell et al. demonstrated that alcohol administered at a higher concentration $(40 \%(v / v))$ and dose $(0.8 \mathrm{~g} / \mathrm{kg})$ increased peak gamma power in both the human visual and motor cortices and decreased peak gamma frequency in the visual cortex [67]. 
Table 6. Clinical Studies of Alcohol and Gamma Oscillations.

\begin{tabular}{|c|c|c|c|c|}
\hline Study & $\begin{array}{l}\text { Gamma Frequency } \\
\text { Range and Type }\end{array}$ & Subject Information & $\begin{array}{l}\text { Method of } \\
\text { Administration }\end{array}$ & Main Findings \\
\hline $\begin{array}{l}\text { Jaaskelainen et al. } \\
(2000)\end{array}$ & 40-Hz; Evoked & $\begin{array}{l}10 \text { Social drinkers } \\
\text { FHNFA * } \\
\text { ( } 5 \text { males and } 5 \text { females; } \\
\text { age: } 20-28 \text { years) }\end{array}$ & $\begin{array}{l}0.25,0.50, \text { or } 0.75 \mathrm{~g} / \mathrm{kg} \\
\text { of } 10 \%(v / v) \text { ethanol } \\
\text { solution or placebo }\end{array}$ & $\begin{array}{l}\text { No differences in gamma power } \\
\text { after consuming } 0.25 \mathrm{~g} / \mathrm{kg} \text {. } \\
\text { Decreased gamma power } \\
\text { following ingestion of the } \\
0.50 \mathrm{~g} / \mathrm{kg} \text { and } 0.75 \mathrm{~g} / \mathrm{kg} \text { doses. }\end{array}$ \\
\hline $\begin{array}{l}\text { De Bruin et al. } \\
\text { (2004) }\end{array}$ & $30-45 \mathrm{~Hz}$ & $\begin{array}{l}22 \text { Male social drinkers } \\
\text { FHNFA (11 light } \\
\text { drinkers: <360 g } \\
\text { alcohol per week; } \\
11 \text { heavy drinkers: } \\
\text { >360 g alcohol per } \\
\text { week; age: } 22-27 \text { years) }\end{array}$ & - & $\begin{array}{l}\text { Increased gamma and theta } \\
(4-8 \mathrm{~Hz}) \text { synchronization in } \\
\text { heavy drinkers compared to } \\
\text { light drinkers. } \\
\text { Insignificant between-group } \\
\text { differences in relative gamma } \\
\text { and theta power. }\end{array}$ \\
\hline $\begin{array}{l}\text { Padmanabhapillai } \\
\text { et al. (2006a) }\end{array}$ & $\begin{array}{l}29-45 \mathrm{~Hz} \\
\text { Evoked }\end{array}$ & $\begin{array}{l}122 \text { people with } \\
\text { alcoholism (male; age: } \\
\text { 20-40 years), } 72 \text { social } \\
\text { drinkers FHNFA (male; } \\
\text { age: } 19-36 \text { years) }\end{array}$ & - & $\begin{array}{l}\text { Decreased frontal gamma power } \\
\text { in alcoholics compared to } \\
\text { controls during target processing. } \\
\text { Increased frontal gamma power } \\
\text { in alcoholics compared to } \\
\text { controls during non-target } \\
\text { processing. }\end{array}$ \\
\hline $\begin{array}{l}\text { Padmanabhapillai } \\
\text { et al. (2006b) }\end{array}$ & $\begin{array}{l}29-45 \mathrm{~Hz} \\
\text { Evoked }\end{array}$ & $\begin{array}{l}68 \text { Male adolescents } \\
\text { with at least one } \\
\text { alcohol-dependent } \\
\text { parent (high-risk), } \\
27 \text { male adolescents } \\
\text { from non-alcoholic } \\
\text { families (low-risk) }\end{array}$ & - & $\begin{array}{l}\text { Decreased frontal and parietal } \\
\text { gamma band response in } \\
\text { high-risk adolescents compared } \\
\text { to controls during target } \\
\text { processing. } \\
\text { No change in gamma activity } \\
\text { between target, non-target and } \\
\text { novel stimuli conditions in the } \\
\text { high-risk group. }\end{array}$ \\
\hline
\end{tabular}

* FHNFA: family-history negative for alcoholism.

Padmanabhapillai and colleagues investigated early evoked gamma oscillations in 122 alcohol-dependent individuals and 72 healthy controls during a visual oddball task [68]. In this study, alcoholic subjects reported an average of 10.07 drinks per drinking day. Controls were social drinkers with a mean of 1.68 drinks per drinking day. Gamma activity was found to be significantly lower in alcoholics during target stimuli processing compared to controls but significantly higher during non-target processing [68]. In addition to evoked gamma power, reductions in evoked delta and theta band activity during stimulus processing have also been previously reported in patients with chronic alcoholism [69]. Following a similar experimental design, the same group then investigated early evoked gamma oscillations in male adolescents at high risk for alcoholism [68]. Consistent with alcohol-dependent individuals, high-risk adolescents also exhibited lower evoked gamma power during target processing in both the frontal and parietal regions compared to controls [68]. Furthermore, while control subjects displayed higher evoked gamma band responses in target-present conditions compared to non-target and novel-stimuli conditions, high-risk subjects did not display this pattern [68]. Moreover, De Bruin and colleagues demonstrated that heavy alcohol drinkers may also undergo changes in hippocampalneocortical connectivity [70]. In this study, 11 male heavy drinkers and 11 male light drinkers participated in two EEG recording sessions. Heavy drinkers were defined as consuming over $360 \mathrm{~g}$ of alcohol per week whereas light drinkers consumed less than $360 \mathrm{~g}$ per week. Heavy drinkers exhibited higher theta and gamma synchronization compared to light drinkers in both conditions [70].

To summarize, the relationship between alcohol and gamma band activity appears to be a dose-dependent and inverted U-shaped pattern-administration at a low dosage 
generally increases gamma power while gamma activity is suppressed by alcohol at intoxicating concentrations. In addition, chronic alcohol consumption may lead to reduced gamma power as well as altered brain connectivity, which may underlie impaired cognitive function observed with severe AUDs.

Tobacco: Gamma activity following acute nicotine exposure has also been studied in human tobacco smokers (Table 7). Crawford and colleagues examined sensory gating, P50, and auditory evoked gamma oscillations, among sex- and age-matched cigarette smokers and never-smokers [71]. In this study, smokers had smoked for more than 5 years and currently smoke at least 20 cigarettes per day. Both groups of participants were tested in two conditions-smokers tested after overnight abstinence and after smoking, while controls did not smoke. Sensory gating refers to the process of filtering stimuli, by separating irrelevant stimuli from meaningful stimuli [72]. Crawford et al. examined sensory gating using a paired-tone paradigm, where two identical auditory tones are played 50-milliseconds apart, and participant sensory gating levels are measured by calculating the ratio of P50 event-related potential amplitudes [71]. They found that smokers had significantly greater gamma power compared to never-smokers and also displayed greater sensory gating both before and after abstinence [71].

Table 7. Clinical Studies of Tobacco on Gamma Oscillations.

\begin{tabular}{|c|c|c|c|c|}
\hline Study & $\begin{array}{l}\text { Gamma Frequency } \\
\text { Range and Type }\end{array}$ & Subject Information & $\begin{array}{l}\text { Method of } \\
\text { Administration }\end{array}$ & Main Findings \\
\hline $\begin{array}{l}\text { Crawford } \\
\text { et al. (2002) }\end{array}$ & $\begin{array}{l}32-48 \mathrm{~Hz} \\
\text { Evoked }\end{array}$ & $\begin{array}{l}13 \text { Heavy cigarette } \\
\text { smokers (>20 cigarettes } \\
\text { per day) and } 13 \text { age- and } \\
\text { sex-matched } \\
\text { never-smokers (age: } \\
20-40 \text { years) }\end{array}$ & $\begin{array}{l}\text { Smokers were assessed } \\
\text { following overnight } \\
\text { (9-15 h) abstinence and } \\
\text { after smoking their } \\
\text { usual brand } \\
\text { of cigarettes }\end{array}$ & $\begin{array}{l}\text { Increased gamma power in } \\
\text { smokers versus controls. }\end{array}$ \\
\hline $\begin{array}{l}\text { Wilbanks } \\
\text { et al. (2016) }\end{array}$ & $30-80 \mathrm{~Hz}$ & $\begin{array}{l}35 \text { Smokers and } 35 \text { age- } \\
\text { and demographically } \\
\text { matched never-smokers } \\
\text { three months postpartum }\end{array}$ & - & $\begin{array}{l}\text { - No change in gamma, high } \\
\text { alpha }(10.5-13 \mathrm{~Hz}) \text {, and beta } \\
(13-30 \mathrm{~Hz}) \text { power between } \\
\text { smoking and non-smoking } \\
\text { mothers. } \\
\text { Increased delta }(1-4 \mathrm{~Hz}), \text { theta } \\
(4-8 \mathrm{~Hz}) \text { and low alpha } \\
(8-10.5 \mathrm{~Hz}) \text { power in smokers } \\
\text { compared to controls. }\end{array}$ \\
\hline
\end{tabular}

No study to date has yet examined changes in gamma band activity in human subjects following a prolonged nicotine administration paradigm. However, a study by Wilbanks et al. did examine the impact of tobacco smoking on resting neural oscillations in postpartum mothers [73]. Although delta, theta, and alpha power were found to be elevated in smokers, no significant difference in gamma oscillatory power was observed in smoking mothers compared to controls [73] (Table 7).

Generally, nicotine administration increases gamma band activity. In chronic tobacco smokers-compared to never-smokers, smokers have higher gamma power. The above findings support the hypothesis that nicotine may help improve neurocognitive dysfunction in individuals with schizophrenia [74] through the modulation of gamma oscillations [75].

Cannabis: Studies of acute THC administration in human populations suggest that cannabis disrupts gamma oscillatory activity (Table 8). Nottage and colleagues investigated the effects of intravenous THC on high-frequency EEG recordings compared to placebo in participants with prior exposure to cannabis use but who were not cannabis-dependent [76]. THC shifted oscillatory activities towards higher frequencies such that there was a decrease 
in high beta oscillation $(21-27 \mathrm{~Hz})$ and increased low gamma $(27-45 \mathrm{~Hz})$ at rest. Furthermore, reductions in the high beta range $(21-27 \mathrm{~Hz})$ were more prominent in anterior regions, while posterior regions generally showed increases in the low gamma range $(27-45 \mathrm{~Hz})$. The THC-induced shift to faster gamma oscillations resulting in a hyperactive cortex may be associated with saliency misattribution in delusional states observed with psychosis.

Table 8. Clinical Studies of Cannabis on Gamma Oscillations.

\begin{tabular}{|c|c|c|c|c|}
\hline Study & $\begin{array}{l}\text { Gamma Frequency } \\
\text { Range and Type }\end{array}$ & $\begin{array}{l}\text { Subject } \\
\text { Information }\end{array}$ & $\begin{array}{l}\text { Method of } \\
\text { Administration }\end{array}$ & Main Findings \\
\hline $\begin{array}{l}\text { Nottage et al. } \\
2015\end{array}$ & $\begin{array}{l}\text { Resting state low gamma } \\
(35-45 \mathrm{~Hz} \text { ad } \\
\text { event-related } \\
\text { synchronization (ERS) } \\
\text { during motor associated } \\
\text { high gamma }(65-85 \mathrm{~Hz})\end{array}$ & $\begin{array}{l}14 \text { Human } \\
\text { Subjects }\end{array}$ & $\begin{array}{l}\text { Intravenous } \mathrm{THC} \\
(1.25 \mathrm{mg})\end{array}$ & $\begin{array}{l}\text { THC induced a shift to faster gamma } \\
\text { oscillations and may represent an } \\
\text { over-activation of the cortex that was } \\
\text { related to positive symptoms. }\end{array}$ \\
\hline $\begin{array}{l}\text { Cortes-Briones } \\
\text { et al. } 2015\end{array}$ & $\begin{array}{l}\text { Auditory steady-state at } \\
20,30, \text { and } 40 \mathrm{~Hz} \text { evoked } \\
\text { potentials (Inter-trial } \\
\text { coherence and evoked } \\
\text { power } \sim 40 \mathrm{~Hz} \text { ) }\end{array}$ & $\begin{array}{l}\text { Human Subjects } \\
n=20\end{array}$ & $\begin{array}{l}\text { Intravenous THC } \\
(0.003 \mathrm{mg} / \mathrm{kg})\end{array}$ & $\begin{array}{l}\text { THC reduced ITC in the } 40 \mathrm{~Hz} \\
\text { condition and evoked gamma power } \\
\text { compared to placebo } \\
\text { Negative correlation was observed } \\
\text { between } 40 \mathrm{~Hz} \text { ITC and } \\
\text { PANSS subscales }\end{array}$ \\
\hline $\begin{array}{l}\text { Skosnik et al. } \\
2006\end{array}$ & $\begin{array}{l}\text { Auditory steady-state } \\
\text { evoked potentials } \\
\text { (spectral power) during } \\
\text { auditory click trains of 20, } \\
30 \text {, and } 40 \mathrm{~Hz} \text { ) }\end{array}$ & $\begin{array}{l}\text { Human Subjects } \\
\text { (Current } \\
\text { cannabis users } \\
n=17 \text { and drug } \\
\text { naïve } n=16 \text { ) }\end{array}$ & - & $\begin{array}{l}\text { Reduced power during the } 20 \mathrm{~Hz} \\
\text { stimulation frequency among cannabis } \\
\text { users that were correlated with } \\
\text { schizotypal personality } \\
\text { questionnaire scores. }\end{array}$ \\
\hline $\begin{array}{l}\text { Skosik et al. } \\
2012\end{array}$ & $\begin{array}{l}\text { Auditory steady-state } \\
\text { evoked potentials } \\
\text { (spectral power) during } \\
\text { auditory click trains at } 9 \\
\text { different frequencies) }\end{array}$ & $\begin{array}{l}\text { Human Subjects } \\
\text { (Chronic } \\
\text { cannabis users } \\
n=22 \text { and } \\
\text { cannabis naïve } \\
\text { controls } n=24 \text { ) }\end{array}$ & - & $\begin{array}{l}\text { Decreased spectral power was observed } \\
\text { among cannabis users. } \\
\text { Reduced gamma power was related to } \\
\text { an earlier age of onset of cannabis use. } \\
\text { No effects on phase-locking or the N100, } \\
\text { suggesting that cannabis may selectively } \\
\text { impair the ability to generate } \\
\text { oscillations in the gamma } \\
\text { frequency range. }\end{array}$ \\
\hline $\begin{array}{l}\text { Edwards et al. } \\
2009\end{array}$ & $\begin{array}{l}\text { Gamma range }(30-50 \mathrm{~Hz}) \\
\text { during event-related } \\
\text { spectral perturbations } \\
\text { (ERSP) and inter-trial } \\
\text { coherence (ITC) }\end{array}$ & $\begin{array}{l}\text { Human Subjects } \\
\text { (Heavy } \\
\text { cannabis users } \\
n=17 \text { and } \\
\text { cannabis naïve } \\
n=16 \text { ) }\end{array}$ & - & $\begin{array}{l}\text { Reduced P50 gating and attenuated ITC } \\
\text { among heavy cannabis users compared } \\
\text { to controls in the beta and gamma } \\
\text { frequency ranges. }\end{array}$ \\
\hline $\begin{array}{l}\text { Skosnik et al. } \\
2014\end{array}$ & $\begin{array}{l}\text { Gamma oscillations } \\
(40-59 \mathrm{~Hz}) \text { during } \\
\text { coherent motion } \\
\text { perception }\end{array}$ & $\begin{array}{l}\text { Human Subjects } \\
\text { (Chronic } \\
\text { cannabis users } \\
n=34 \text { and } \\
\text { cannabis naïve } \\
n=23 \text { ) }\end{array}$ & - & $\begin{array}{l}\text { Gamma power was reduced during } \\
\text { coherent motion perception among } \\
\text { cannabis users compared to controls. } \\
\text { No differences were found between } \\
\text { N100 or P200. } \\
\text { Cannabis may interfere with the } \\
\text { generation of gamma oscillations that } \\
\text { may mediate perceptual alterations. }\end{array}$ \\
\hline
\end{tabular}

Another study by Cortes-Briones and colleagues also demonstrated the association between THC and effects on the positive and negative symptom scale (PANSS) - an index used among patients with schizophrenia. In this study, an auditory steady-state response paradigm to probe the effects of acute THC administration on broadband-frequency neural oscillations and its relation to psychosis-related effects in healthy, cannabis naïve, and recreational users [77]. Auditory steady-state evoked potentials were assessed in both cannabis 
using and cannabis naïve subjects at varying auditory stimulation frequencies. The study demonstrated for the first time that acute THC administration induces a dose-dependent reduction of intertrial coherence (ITC) at $40 \mathrm{~Hz}$ stimulation frequency, suggesting that exogenous THC disrupts time-locked gamma band activity. Moreover, there was an inverse relationship between ITC and positive symptoms as measured by the PANSS, implicating gamma activity in positive symptom presentation among a healthy population. These findings from acute administration trials thus provide evidence that cannabis use disrupts gamma band activity among the general population. Moreover, the effect of THC on gamma oscillations may represent the pathophysiological mechanism through which psychosis is mediated.

Clinical studies examining chronic cannabis use and its effects on EEG recordings provide further evidence that cannabinoid exposure contributes to positive symptoms in psychosis by disrupting gamma band activity. Researchers used the auditory steady-state response paradigm to examine the effects of chronic cannabis use on broadband-frequency neural oscillations in cannabis using and cannabis naïve controls [78]. Cannabis users showed reduced evoked $40 \mathrm{~Hz}$ harmonic during $20 \mathrm{~Hz}$ stimulation frequencies compared to controls. Evoked power values at $20 \mathrm{~Hz}$ stimulation frequency were also negatively correlated with scores of schizotypal personality characteristics. Cannabis using subjects demonstrated increased schizotypal characteristics compared to cannabis naïve subjects as assessed by the Schizotypal Personality Questionnaire. Total years of cannabis use were also positively correlated with higher measures of schizotypal characteristics. In a follow-up study, Skosnik again used the auditory steady-state response paradigm to investigate disruptions in broadband EEG neural oscillation associated with cannabis use in a larger sample with more variations in click-train frequencies [79]. Results showed a selective and significant decrease in Fourier-based mean trial power (MTP) at $40 \mathrm{~Hz}$ among cannabis users compared to cannabis naïve controls, while an earlier onset of cannabis use was associated with lower oscillatory power at $40 \mathrm{~Hz}$. Edwards and colleagues investigated the effects of chronic cannabis use on auditory evoked neural oscillation and auditory P50 sensory gating [80]. Results from event-related spectral perturbations (ERSP) analysis showed abnormal high-frequency activity in gamma range $(30-50 \mathrm{~Hz})$ in cannabis users following auditory stimulation. Cannabis users demonstrated a timespecific reduction in power in high-frequency gamma and beta bands following the first stimulus (S1) and reductions in just gamma power following the second stimulus (S2). P50 gating was reduced in the cannabis using population compared to cannabis naïve controls in a manner that is similar to gating disturbances found among patients with schizophrenia. Additionally, greater levels of cannabis use were associated with high P50 ratios and negatively correlated with ERSP gamma power [80]. In a study assessing gamma oscillation during a coherent motion task in chronic cannabis users and cannabis naïve controls, cannabis users demonstrated a significant decrease in induced gamma power in coherent conditions compared to controls [81]. Moreover, an increasing trend in the Perceptual Aberration Scale (PAS), with higher scores positively correlated with total years of cannabis use, was observed among chronic cannabis users [81] (Table 8).

Overall, these studies suggest that cannabis, and particularly THC, decreases gamma activity. Clinical studies indicate that the disruption of gamma activity resulting from both acute THC administration and chronic cannabis use is associated with central nervous system hyperexcitability and positive symptomatology typically observed in psychosis.

Cocaine: One human study examined attentional bias to drug related cues by measuring evoked and induced gamma reactivity measure in patients with cocaine use disorder before and following motivational interview-based neurofeedback treatment [82] (Table 9). It is interesting to note that out of 10 participants, 7 also tested positive for cannabis use. Following 12 sessions of treatment, cocaine use decreased marginally while cannabis use significantly decreased for all patients. EEG reactivity to drug related cues was decreased post-treatment and, specifically, both evoked and induced gamma power decreased globally for drug related cues and non-drug related cues. While it is difficult to correlate 
the decreased cocaine usage to changes in neurophysiology given the nature of the selfreporting method, the accidental finding of dramatic decreases in cannabis use further cofounds the investigation into cocaine effects on gamma oscillations.

Table 9. Clinical Studies of Cocaine on Gamma Oscillations.

\begin{tabular}{|c|c|c|c|c|}
\hline Study & $\begin{array}{l}\text { Gamma Frequency } \\
\text { Range and Type }\end{array}$ & Subject Information & $\begin{array}{l}\text { Method of } \\
\text { Administration }\end{array}$ & Main Findings \\
\hline Horrell et al. 2010 & $\begin{array}{l}\text { Evoked and induced } \\
\text { gamma power } \\
(30-40 \mathrm{~Hz})\end{array}$ & $\begin{array}{l}\text { Human Subjects } \\
\text { (Current cocaine } \\
\text { abusers } n=10 \text { ) }\end{array}$ & - & $\begin{array}{l}\text { Decreased regional evoked and } \\
\text { induced gamma power to } \\
\text { non-target and target cues. } \\
\text { Induced gamma power to } \\
\text { non-target and target cues was } \\
\text { reduced globally. }\end{array}$ \\
\hline
\end{tabular}

Only two studies reported on cocaine and gamma activity (Table 9). Dilgen et al. found a decrease in gamma activity following acute administration of cocaine in a preclinical population [63]. Horrell et al. found decreased gamma activity among chronic cocaine users, persisting post-treatment [82]. These studies suggest that cocaine use may result in long-term decreases in gamma activity.

\section{Discussion}

In this paper, we provide a comprehensive review of current evidence on alcohol, tobacco, cannabis, cocaine, and amphetamine use on gamma oscillatory activity during acute, chronic, and withdrawal states, among preclinical and clinical populations. All substances were associated with modulated gamma activity, in both preclinical and clinical populations and across states. Moreover, gamma appeared to be differentially modulated by acute versus chronic exposure, which may be related to cognitive dysfunction associated with substance abuse.

Pre-clinical studies indicated that all five substances modulated gamma activity. Alcohol use displayed an inverted U-shaped pattern during exposure for gamma and an increase across all frequencies during withdrawal. Tobacco use resulted in increased gamma during both acute and chronic exposure. Acute cannabis and cocaine exposure resulted in a decrease in gamma. Amphetamine use had mixed effects on gamma activity.

Similarly, clinical studies demonstrated that alcohol, tobacco, and cannabis modulated gamma activity. Acute alcohol exposure resulted in a selective decrease in gamma among non-dependent individuals, while such decreases were observed across all frequency bands among dependent individuals. Chronic tobacco use led to an increase in gamma, whereas chronic cannabis use led to a decrease in gamma. Clinical studies of cocaine and amphetamine were limited, making it difficult to draw any patterns on their influence on gamma. Thus, it appears that alcohol may act differently than other substances.

Alcohol and gamma had the most complex relationship, with alcohol decreasing gamma during withdrawal and in non-dependent individuals but displaying an inverted Ushaped pattern during exposure. Findings were mixed, likely to do studies varying in tasks used, types of controls (e.g., social drinkers, light drinkers, never drinkers), participant state (i.e., exposure versus withdrawal), and whether alcohol exposure was acute or chronic. The preclinical evidence of increased gamma activity during periods of alcohol withdrawal may represent post alcohol withdrawal hyperexcitability, a phenomenon whereby alcohol inhibits NMDAR excitatory signalling and increases GABAR inhibitory signalling, leading to central nervous system suppression and resulting in hyperexcitability during withdrawal $[83,84]$. The clinical evidence of varying effects of alcohol on gamma based on the task used suggests that there may be differential effects of alcohol based on the brain area involved and the type of cognition involved, a finding previously noted in the literature [85-87]. These findings indicate that several brain areas may be involved in the neuropathology of AUDs. 
This review contains several strengths and limitations. We searched multiple databases and followed the PRISMA reporting guidelines to ensure a rigorous standard of review and reporting. We also searched for a variety of terms in order to capture all potentially relevant studies. A limitation of this review was that we only reviewed the five most common SUDs (alcohol, tobacco, cannabis, cocaine, and amphetamine), potentially limiting the generalizability of findings to other substances. Next, we did not directly search for the term "schizophrenia" or "psychosis"; we instead focused on search terms related to gamma, EEG, and SUDs and then manually screened for studies including patients with schizophrenia. This may have led to unintended exclusion of relevant studies. Last, we excluded studies of gamma in other disease areas, such as the effects of gamma entrainment therapies on brain pathology and cognitive symptoms in Alzheimer's disease (e.g., [87-89]). This may have omitted potentially relevant studies; however, we intentionally focused on SUDs and schizophrenia, given the prevalence and lack of research on these disorders.

\section{Conclusions and Implications}

The findings of this review indicate that both acute and chronic substance use modulate gamma activity and do so across different states. These findings offer insights into the potential mechanism underlying the pathophysiology of SUDs. This review also contributes to the growing body of evidence indicating the potential for brain stimulation to address deficits associated with SUDs. Brain stimulation treatments, such as transcranial direct current stimulation and repetitive transcranial magnetic stimulation, that modulate gamma activity may offer a promising potential approach for targeting working memory. Further research is needed to fully understand the underlying pathophysiology of SUDs in order to advance treatment of these devastating disorders and reduce the global burden on healthcare systems.

Author Contributions: Conceptualization, M.S.B., R.Z. and Y.N.; methodology, M.S.B. and J.U.R.; software, M.S.B. and J.U.R.; validation, M.S.B.; formal analysis, M.S.B., J.U.R. and M.M.; investigation, M.S.B.; resources, M.S.B.; data curation, M.S.B., J.U.R. and M.M.; writing—original draft preparation, M.S.B., J.U.R. and M.M.; writing-review and editing, D.M.B., R.Z., Y.N. and M.S.B.; visualization, M.S.B. and J.U.R.; supervision, M.S.B.; project administration, M.S.B. and J.U.R.; funding acquisition, M.S.B. All authors have read and agreed to the published version of the manuscript.

Funding: M.S.B. has received support from Brain and Behavior Research Foundation (Formerly NARSAD). D.M.B. has received research support from the CIHR, NIH, Brain Canada and the Temerty Family through the CAMH Foundation and the Campbell Research Institute. He received research support and in-kind equipment support for an investigator-initiated study from Brainsway Ltd., and he is the principal site investigator for three sponsor-initiated studies for Brainsway Ltd. He receives in-kind equipment support from Magventure for investigator-initiated research. He received medication supplies for an investigator-initiated trial from Indivior. Y.N. has received a Grant-in-Aid for Young Scientists (KAKENHI) from the Promotion of Science, research grants from Japan Agency for Medical Research and Development (AMED), investigator-initiated clinical study grants from TEIJIN PHARMA LIMITED and Inter Reha Co., Ltd. Y.N. also receives research grants from Japan Health Foundation, Meiji Yasuda Mental Health Foundation, Mitsui Life Social Welfare Foundation, Takeda Science Foundation, SENSHIN Medical Research Foundation, Health Science Center Foundation, Mochida Memorial Foundation for Medical and Pharmaceutical Research, Taiju Life Social Welfare Foundation, and Daiichi Sankyo Scholarship Donation Program. Y.N. has received speaker's honoraria from Dainippon Sumitomo Pharma, MOCHIDA PHARMACEUTICAL Co., Ltd., and Yoshitomiyakuhin Corporation within the past three years. Y.N. also receives equipment-inkind support for an investigator-initiated study from Magventure Inc., Inter Reha Co., Ltd., Rogue Resolutions Ltd., and Miyuki Giken Co., Ltd.

Acknowledgments: The authors acknowledge Mark X. Wan for his assistance with data collection for this review.

Conflicts of Interest: J.U.R., M.M. and R.Z. declare no conflict of interest. 


\section{References}

1. United Nations Office on Drugs and Crime. World Drug Report 2019 (Set of 5 Booklets); United Nations: New York, NY, USA, 2019; ISBN 978-92-1-004174-4.

2. World Health Organization. Global Status Report on Alcohol and Health 2018; World Health Organization: Geneva, Switzerland, 2018; ISBN 978-92-4-156563-9.

3. World Health Organization. WHO Report on the Global Tobacco Epidemic, 2019: Offer Help to Quit Tobacco Use; World Health Organization: Geneva, Switzerland, 2019; ISBN 978-92-4-151620-4.

4. Baddeley, A. Working Memory: Looking Back and Looking Forward. Nat. Rev. Neurosci. 2003, 4, 829-839. [CrossRef]

5. Brandt, J. Cognitive Loss and Recovery in Long-Term Alcohol Abusers. Arch. Gen. Psychiatry 1983, 40, 435. [CrossRef]

6. Smith, M.J.; Cobia, D.J.; Wang, L.; Alpert, K.I.; Cronenwett, W.J.; Goldman, M.B.; Mamah, D.; Barch, D.M.; Breiter, H.C.; Csernansky, J.G. Cannabis-Related Working Memory Deficits and Associated Subcortical Morphological Differences in Healthy Individuals and Schizophrenia Subjects. Schizophr. Bull. 2014, 40, 287-299. [CrossRef]

7. Pfefferbaum, A.; Rosenbloom, M.; Crusan, K.; Jernigan, T.L. Brain CT Changes in Alcoholics: Effects of Age and Alcohol Consumption. Alcohol. Clin. Exp. Res. 1988, 12, 81-87. [CrossRef]

8. Chanraud, S.; Martelli, C.; Delain, F.; Kostogianni, N.; Douaud, G.; Aubin, H.-J.; Reynaud, M.; Martinot, J.-L. Brain Morphometry and Cognitive Performance in Detoxified Alcohol-Dependents with Preserved Psychosocial Functioning. Neuropsychopharmacology 2007, 32, 429-438. [CrossRef]

9. Kril, J.J.; Halliday, G.M.; Svoboda, M.D.; Cartwright, H. The Cerebral Cortex Is Damaged in Chronic Alcoholics. Neuroscience 1997, 79, 983-998. [CrossRef]

10. Leitz, J.R.; Morgan, C.J.A.; Bisby, J.A.; Rendell, P.G.; Curran, H.V. Global Impairment of Prospective Memory Following Acute Alcohol. Psychopharmacology 2009, 205, 379-387. [CrossRef]

11. do Canto-Pereira, L.H.M.; de P A David, I.; Machado-Pinheiro, W.; Ranvaud, R.D. Effects of Acute Alcohol Intoxication on Visuospatial Attention. Hum. Exp. Toxicol. 2007, 26, 311-319. [CrossRef]

12. Schweizer, T.A.; Jolicoeur, P.; Vogel-Sprott, M.; Dixon, M.J. Fast, but Error-Prone, Responses during Acute Alcohol Intoxication: Effects of Stimulus-Response Mapping Complexity. Alcohol. Clin. Exp. Res. 2004, 28, 643-649. [CrossRef]

13. Harvey, M.A.; Sellman, J.D.; Porter, R.J.; Frampton, C.M. The Relationship between Non-Acute Adolescent Cannabis Use and Cognition. Drug Alcohol Rev. 2007, 26, 309-319. [CrossRef] [PubMed]

14. Solowij, N.; Stephens, R.S.; Roffman, R.A.; Babor, T.; Kadden, R.; Miller, M.; Christiansen, K.; McRee, B.; Vendetti, J. Marijuana Treatment Project Research Group Cognitive Functioning of Long-Term Heavy Cannabis Users Seeking Treatment. JAMA 2002, 287, 1123-1131. [CrossRef]

15. Ardila, A.; Rosselli, M.; Strumwasser, S. Neuropsychological Deficits in Chronic Cocaine Abusers. Int. J. Neurosci. 1991, 57, 73-79. [CrossRef]

16. O'Malley, S.; Adamse, M.; Heaton, R.K.; Gawin, F.H. Neuropsychological Impairment in Chronic Cocaine Abusers. Am. J. Drug Alcohol Abus. 1992, 18, 131-144. [CrossRef]

17. Ranganathan, M.; D'Souza, D.C. The Acute Effects of Cannabinoids on Memory in Humans: A Review. Psychopharmacology 2006, 188, 425-444. [CrossRef]

18. Rentzsch, J.; Stadtmann, A.; Montag, C.; Kunte, H.; Plöckl, D.; Hellweg, R.; Gallinat, J.; Kronenberg, G.; Jockers-Scherübl, M.C. Attentional Dysfunction in Abstinent Long-Term Cannabis Users with and without Schizophrenia. Eur. Arch. Psychiatry Clin. Neurosci. 2016, 266, 409-421. [CrossRef]

19. Ramaekers, J.G.; Kauert, G.; van Ruitenbeek, P.; Theunissen, E.L.; Schneider, E.; Moeller, M.R. High-Potency Marijuana Impairs Executive Function and Inhibitory Motor Control. Neuropsychopharmacology 2006, 31, 2296-2303. [CrossRef]

20. Pope, H.G.; Gruber, A.J.; Hudson, J.I.; Huestis, M.A.; Yurgelun-Todd, D. Neuropsychological Performance in Long-Term Cannabis Users. Arch. Gen. Psychiatry 2001, 58, 909. [CrossRef]

21. Chambers, R.A.; Krystal, J.H.; Self, D.W. A Neurobiological Basis for Substance Abuse Comorbidity in Schizophrenia. Biol. Psychiatry 2001, 50, 71-83. [CrossRef]

22. Berger, H. Über das Elektrenkephalogramm des Menschen. Arch. Psychiatr. Nervenkrankh. 1929, 87, 527-570. [CrossRef]

23. Sederberg, P.B.; Kahana, M.J.; Howard, M.W.; Donner, E.J.; Madsen, J.R. Theta and Gamma Oscillations during Encoding Predict Subsequent Recall. J. Neurosci. 2003, 23, 10809-10814. [CrossRef]

24. Gruber, T.; Müller, M.M.; Keil, A.; Elbert, T. Selective Visual-Spatial Attention Alters Induced Gamma Band Responses in the Human EEG. Clin. Neurophysiol. 1999, 110, 2074-2085. [CrossRef]

25. Tiitinen, H.; Sinkkonen, J.; Reinikainen, K.; Alho, K.; Lavikainen, J.; Näätänen, R. Selective Attention Enhances the Auditory 40-Hz Transient Response in Humans. Nature 1993, 364, 59-60. [CrossRef] [PubMed]

26. Bichot, N.P.; Rossi, A.F.; Desimone, R. Parallel and Serial Neural Mechanisms for Visual Search in Macaque Area V4. Science 2005, 308, 529-534. [CrossRef] [PubMed]

27. Ossandón, T.; Vidal, J.R.; Ciumas, C.; Jerbi, K.; Hamamé, C.M.; Dalal, S.S.; Bertrand, O.; Minotti, L.; Kahane, P.; Lachaux, J.-P. Efficient "Pop-out" Visual Search Elicits Sustained Broadband $\gamma$ Activity in the Dorsal Attention Network. J. Neurosci. 2012, 32, 3414-3421. [CrossRef] [PubMed]

28. Miltner, W.H.; Braun, C.; Arnold, M.; Witte, H.; Taub, E. Coherence of Gamma-Band EEG Activity as a Basis for Associative Learning. Nature 1999, 397, 434-436. [CrossRef] [PubMed] 
29. Barr, M.S.; Farzan, F.; Rusjan, P.M.; Chen, R.; Fitzgerald, P.B.; Daskalakis, Z.J. Potentiation of Gamma Oscillatory Activity through Repetitive Transcranial Magnetic Stimulation of the Dorsolateral Prefrontal Cortex. Neuropsychopharmacology 2009, 34, $2359-2367$. [CrossRef] [PubMed]

30. Basar-Eroglu, C.; Brand, A.; Hildebrandt, H.; Karolina Kedzior, K.; Mathes, B.; Schmiedt, C. Working Memory Related Gamma Oscillations in Schizophrenia Patients. Int. J. Psychophysiol. 2007, 64, 39-45. [CrossRef]

31. Howard, M.W.; Rizzuto, D.S.; Caplan, J.B.; Madsen, J.R.; Lisman, J.; Aschenbrenner-Scheibe, R.; Schulze-Bonhage, A.; Kahana, M.J. Gamma Oscillations Correlate with Working Memory Load in Humans. Cereb. Cortex 2003, 13, 1369-1374. [CrossRef]

32. Barr, M.S.; Farzan, F.; Tran, L.C.; Chen, R.; Fitzgerald, P.B.; Daskalakis, Z.J. Evidence for Excessive Frontal Evoked Gamma Oscillatory Activity in Schizophrenia during Working Memory. Schizophr. Res. 2010, 121, 146-152. [CrossRef]

33. Bragin, A.; Jandó, G.; Nádasdy, Z.; Hetke, J.; Wise, K.; Buzsáki, G. Gamma (40-100 Hz) Oscillation in the Hippocampus of the Behaving Rat. J. Neurosci. 1995, 15, 47-60. [CrossRef]

34. Brosch, M.; Budinger, E.; Scheich, H. Stimulus-Related Gamma Oscillations in Primate Auditory Cortex. J. Neurophysiol. 2002, 87, 2715-2725. [CrossRef] [PubMed]

35. Buhl, E.H.; Tamás, G.; Fisahn, A. Cholinergic Activation and Tonic Excitation Induce Persistent Gamma Oscillations in Mouse Somatosensory Cortex In Vitro. J. Physiol. 1998, 513, 117-126. [CrossRef] [PubMed]

36. Fries, P.; Reynolds, J.H.; Rorie, A.E.; Desimone, R. Modulation of Oscillatory Neuronal Synchronization by Selective Visual Attention. Science 2001, 291, 1560-1563. [CrossRef] [PubMed]

37. Gray, C.M.; Singer, W. Stimulus-Specific Neuronal Oscillations in Orientation Columns of Cat Visual Cortex. Proc. Natl. Acad. Sci. USA 1989, 86, 1698-1702. [CrossRef]

38. Cunningham, M.O.; Davies, C.H.; Buhl, E.H.; Kopell, N.; Whittington, M.A. Gamma Oscillations Induced by Kainate Receptor Activation in the Entorhinal Cortex In Vitro. J. Neurosci. 2003, 23, 9761-9769. [CrossRef] [PubMed]

39. Beshel, J.; Kopell, N.; Kay, L.M. Olfactory Bulb Gamma Oscillations Are Enhanced with Task Demands. J. Neurosci. 2007, 27, 8358-8365. [CrossRef]

40. Sato, W.; Kochiyama, T.; Uono, S.; Matsuda, K.; Usui, K.; Inoue, Y.; Toichi, M. Temporal Profile of Amygdala $\gamma$ Oscillations in Response to Faces. J. Cogn. Neurosci. 2012, 24, 1420-1433. [CrossRef]

41. Lewis, D.A.; Hashimoto, T.; Volk, D.W. Cortical Inhibitory Neurons and Schizophrenia. Nat. Rev. Neurosci. 2005, 6, 312-324. [CrossRef]

42. Gray, C.M.; McCormick, D.A. Chattering Cells: Superficial Pyramidal Neurons Contributing to the Generation of Synchronous Oscillations in the Visual Cortex. Science 1996, 274, 109-113. [CrossRef]

43. Whittington, M.A.; Traub, R.D.; Jefferys, J.G.R. Synchronized Oscillations in Interneuron Networks Driven by Metabotropic Glutamate Receptor Activation. Nature 1995, 373, 612-615. [CrossRef]

44. Bartos, M.; Vida, I.; Jonas, P. Synaptic Mechanisms of Synchronized Gamma Oscillations in Inhibitory Interneuron Networks. Nat. Rev. Neurosci. 2007, 8, 45-56. [CrossRef] [PubMed]

45. Wang, X.-J.; Buzsáki, G. Gamma Oscillation by Synaptic Inhibition in a Hippocampal Interneuronal Network Model. J. Neurosci. 1996, 16, 6402-6413. [CrossRef] [PubMed]

46. Fisahn, A.; Pike, F.G.; Buhl, E.H.; Paulsen, O. Cholinergic Induction of Network Oscillations at $40 \mathrm{~Hz}$ in the Hippocampus In Vitro. Nature 1998, 394, 186-189. [CrossRef] [PubMed]

47. Fisahn, A.; Contractor, A.; Traub, R.D.; Buhl, E.H.; Heinemann, S.F.; McBain, C.J. Distinct Roles for the Kainate Receptor Subunits GluR5 and GluR6 in Kainate-Induced Hippocampal Gamma Oscillations. J. Neurosci. 2004, 24, 9658-9668. [CrossRef]

48. Faulkner, H.J.; Traub, R.D.; Whittington, M.A. Anaesthetic/Amnesic Agents Disrupt Beta Frequency Oscillations Associated with Potentiation of Excitatory Synaptic Potentials in the Rat Hippocampal Slice. Br. J. Pharm. 1999, 128, 1813-1825. [CrossRef]

49. Moher, D.; Liberati, A.; Tetzlaff, J.; Altman, D.G. PRISMA Group Preferred Reporting Items for Systematic Reviews and Meta-Analyses: The PRISMA Statement. PLoS Med. 2009, 6, e1000097. [CrossRef]

50. Wang, J.; Zhao, J.; Liu, Z.; Guo, F.; Wang, Y.; Wang, X.; Zhang, R.; Vreugdenhil, M.; Lu, C. Acute Ethanol Inhibition of $\gamma$ Oscillations Is Mediated by Akt and GSK3ß. Front. Cell. Neurosci. 2016, 10. [CrossRef]

51. Tsurugizawa, T.; Abe, Y.; Le Bihan, D. Water Apparent Diffusion Coefficient Correlates with Gamma Oscillation of Local Field Potentials in the Rat Brain Nucleus Accumbens Following Alcohol Injection. J. Cereb. Blood Flow Metab. 2017, 37, $3193-3202$. [CrossRef]

52. Ehlers, C.L.; Chaplin, R.I. EEG and ERP Response to Chronic Ethanol Exposure in Rats. Psychopharmacology 1991, 104, 67-74. [CrossRef]

53. Slawecki, C.J. Altered EEG Responses to Ethanol in Adult Rats Exposed to Ethanol During Adolescence. Alcohol. Clin. Exp. Res. 2002, 26, 246-254. [CrossRef]

54. Cheaha, D.; Sawangjaroen, K.; Kumarnsit, E. Characterization of Fluoxetine Effects on Ethanol Withdrawal-Induced Cortical Hyperexcitability by EEG Spectral Power in Rats. Neuropharmacology 2014, 77, 49-56. [CrossRef] [PubMed]

55. Phillips, J.M.; Ehrlichman, R.S.; Siegel, S.J. Mecamylamine Blocks Nicotine-Induced Enhancement of the P20 Auditory Event Related Potential and Evoked Gamma. Neuroscience 2007, 144, 1314-1323. [CrossRef] [PubMed]

56. Song, C.; Murray, T.A.; Kimura, R.; Wakui, M.; Ellsworth, K.; Javedan, S.P.; Marxer-Miller, S.; Lukas, R.J.; Wu, J. Role of A7Nicotinic Acetylcholine Receptors in Tetanic Stimulation-Induced $\gamma$ Oscillations in Rat Hippocampal Slices. Neuropharmacology 2005, 48, 869-880. [CrossRef] [PubMed] 
57. Zhang, X.; Ge, X.Y.; Wang, J.G.; Wang, Y.L.; Wang, Y.; Yu, Y.; Li, P.P.; Lu, C.B. Induction of Long-Term Oscillations in the $\gamma$ Frequency Band by NAChR Activation in Rat Hippocampal CA3 Area. Neuroscience 2015, 301, 49-60. [CrossRef]

58. Wang, Y.; Wang, Z.; Wang, J.; Wang, Y.; Henderson, Z.; Wang, X.; Zhang, X.; Song, J.; Lu, C. The Modulation of Nicotinic Acetylcholine Receptors on the Neuronal Network Oscillations in Rat Hippocampal CA3 Area. Sci. Rep. 2015, 5, 9493. [CrossRef]

59. Akkurt, D.; Akay, Y.M.; Akay, M. Investigating the Synchronization of Hippocampal Neural Network in Response to Acute Nicotine Exposure. J. Neuroeng. Rehabil. 2010, 7, 31. [CrossRef]

60. Bueno-Junior, L.S.; Simon, N.W.; Wegener, M.A.; Moghaddam, B. Repeated Nicotine Strengthens Gamma Oscillations in the Prefrontal Cortex and Improves Visual Attention. Neuropsychopharmacology 2017, 42, 1590-1598. [CrossRef]

61. Raver, S.M.; Haughwout, S.P.; Keller, A. Adolescent Cannabinoid Exposure Permanently Suppresses Cortical Oscillations in Adult Mice. Neuropsychopharmacology 2013, 38, 2338-2347. [CrossRef]

62. Raver, S.M.; Keller, A. Permanent Suppression of Cortical Oscillations in Mice after Adolescent Exposure to Cannabinoids: Receptor Mechanisms. Neuropharmacology 2014, 86, 161-173. [CrossRef]

63. Dilgen, J.E.; Tompa, T.; Saggu, S.; Naselaris, T.; Lavin, A. Optogenetically Evoked Gamma Oscillations Are Disturbed by Cocaine Administration. Front. Cell. Neurosci. 2013, 7. [CrossRef]

64. Janetsian, S.S.; Linsenbardt, D.N.; Lapish, C.C. Memory Impairment and Alterations in Prefrontal Cortex Gamma Band Activity Following Methamphetamine Sensitization. Psychopharmacology 2015, 232, 2083-2095. [CrossRef] [PubMed]

65. Morra, J.T.; Glick, S.D.; Cheer, J.F. Cannabinoid Receptors Mediate Methamphetamine Induction of High Frequency Gamma Oscillations in the Nucleus Accumbens. Neuropharmacology 2012, 63, 565-574. [CrossRef] [PubMed]

66. Jääskeläinen, I.P.; Hirvonen, J.; Saher, M.; Pekkonen, E.; Sillanaukee, P.; Näätänen, R.; Tiitinen, H. Dose-Dependent Suppression by Ethanol of Transient Auditory 40-Hz Response. Psychopharmacology 2000, 148, 132-135. [CrossRef] [PubMed]

67. Campbell, A.E.; Sumner, P.; Singh, K.D.; Muthukumaraswamy, S.D. Acute Effects of Alcohol on Stimulus-Induced Gamma Oscillations in Human Primary Visual and Motor Cortices. Neuropsychopharmacology 2014, 39, 2104-2113. [CrossRef]

68. Padmanabhapillai, A.; Tang, Y.; Ranganathan, M.; Rangaswamy, M.; Jones, K.A.; Chorlian, D.B.; Kamarajan, C.; Stimus, A.; Kuperman, S.; Rohrbaugh, J.; et al. Evoked Gamma Band Response in Male Adolescent Subjects at High Risk for Alcoholism during a Visual Oddball Task. Int. J. Psychophysiol. 2006, 62, 262-271. [CrossRef]

69. Porjesz, B.; Begleiter, H. Alcoholism and Human Electrophysiology. Alcohol Res. Health 2003, 27, $153-160$.

70. de Bruin, E.A.; Bijl, S.; Stam, C.J.; Böcker, K.B.E.; Kenemans, J.L.; Verbaten, M.N. Abnormal EEG Synchronisation in Heavily Drinking Students. Clin. Neurophysiol. 2004, 115, 2048-2055. [CrossRef]

71. Crawford, H.J.; McClain-Furmanski, D.; Castagnoli, N.; Castagnoli, K. Enhancement of Auditory Sensory Gating and StimulusBound Gamma Band (40 Hz) Oscillations in Heavy Tobacco Smokers. Neurosci. Lett. 2002, 317, 151-155. [CrossRef]

72. Cromwell, H.C.; Mears, R.P.; Wan, L.; Boutros, N.N. Sensory Gating: A Translational Effort from Basic to Clinical Science. Clin. EEG Neurosci. 2008, 39, 69-72. [CrossRef]

73. Wilbanks, H.E.; Von Mohr, M.; Potenza, M.N.; Mayes, L.C.; Rutherford, H.J.V. Tobacco Smoking and the Resting Maternal Brain: A Preliminary Study of Frontal EEG. Yale J. Biol. Med. 2016, 89, 115-122.

74. Freedman, R. A7-Nicotinic Acetylcholine Receptor Agonists for Cognitive Enhancement in Schizophrenia. Annu. Rev. Med. 2014, 65, 245-261. [CrossRef] [PubMed]

75. Uhlhaas, P.J.; Singer, W. High-Frequency Oscillations and the Neurobiology of Schizophrenia. Dialogues Clin. Neurosci. 2013, 15, 301-313. [PubMed]

76. Nottage, J.F.; Stone, J.; Murray, R.M.; Sumich, A.; Bramon-Bosch, E.; ffytche, D.; Morrison, P.D. Delta-9-Tetrahydrocannabinol, Neural Oscillations above $20 \mathrm{~Hz}$ and Induced Acute Psychosis. Psychopharmacology 2015, 232, 519-528. [CrossRef] [PubMed]

77. Cortes-Briones, J.; Skosnik, P.D.; Mathalon, D.; Cahill, J.; Pittman, B.; Williams, A.; Sewell, R.A.; Ranganathan, M.; Roach, B.; Ford, J.; et al. $\triangle 9$-THC Disrupts Gamma ( $\gamma$ )-Band Neural Oscillations in Humans. Neuropsychopharmacol 2015, 40, 2124-2134. [CrossRef]

78. Skosnik, P.D.; Krishnan, G.P.; Aydt, E.E.; Kuhlenshmidt, H.A.; O’Donnell, B.F. Psychophysiological Evidence of Altered Neural Synchronization in Cannabis Use: Relationship to Schizotypy. AJP 2006, 163, 1798-1805. [CrossRef]

79. Skosnik, P.D.; D'Souza, D.C.; Steinmetz, A.B.; Edwards, C.R.; Vollmer, J.M.; Hetrick, W.P.; O'Donnell, B.F. The Effect of Chronic Cannabinoids on Broadband EEG Neural Oscillations in Humans. Neuropsychopharmacology 2012, 37, 2184-2193. [CrossRef]

80. Edwards, C.R.; Skosnik, P.D.; Steinmetz, A.B.; O’Donnell, B.F.; Hetrick, W.P. Sensory Gating Impairments in Heavy Cannabis Users Are Associated with Altered Neural Oscillations. Behav. Neurosci. 2009, 123, 894-904. [CrossRef]

81. Skosnik, P.D.; Krishnan, G.P.; D'Souza, D.C.; Hetrick, W.P.; O'Donnell, B.F. Disrupted Gamma-Band Neural Oscillations During Coherent Motion Perception in Heavy Cannabis Users. Neuropsychopharmacology 2014, 39, 3087-3099. [CrossRef]

82. Horrell, T.; El-Baz, A.; Baruth, J.; Tasman, A.; Sokhadze, G.; Stewart, C.; Sokhadze, E. Neurofeedback Effects on Evoked and Induced EEG Gamma Band Reactivity to Drug-Related Cues in Cocaine Addiction. J. Neurother. 2010, 14, 195-216. [CrossRef]

83. Begleiter, H.; Porjesz, B. Persistence of Brain Hyperexcitability Following Chronic Alcohol Exposure in Rats. In Alcohol Intoxication and Withdrawal-IIIb: Studies in Alcohol Dependence; Gross, M.M., Ed.; Advances in Experimental Medicine and Biology; Springer: Boston, MA, USA, 1977; pp. 209-222. ISBN 978-1-4615-9038-5.

84. Ahveninen, J.; Escera, C.; Polo, M.D.; Grau, C.; Jääskeläinen, I.P. Acute and Chronic Effects of Alcohol on Preattentive Auditory Processing as Reflected by Mismatch Negativity. Audiol. Neurootol. 2000, 5, 303-311. [CrossRef]

85. Loheswaran, G.; Barr, M.S.; Rajji, T.K.; Blumberger, D.M.; Le Foll, B.; Daskalakis, Z.J. Alcohol Intoxication by Binge Drinking Impairs Neuroplasticity. Brain Stimul. 2016, 9, 27-32. [CrossRef] [PubMed] 
86. Ramlakhan, J.U.; Zomorrodi, R.; Downar, J.; Blumberger, D.M.; Daskalakis, Z.J.; George, T.P.; Kiang, M.; Barr, M.S. Using Mismatch Negativity to Investigate the Pathophysiology of Substance Use Disorders and Comorbid Psychosis. Clin. EEG Neurosci. 2018, 49, 226-237. [CrossRef] [PubMed]

87. Martorell, A.J.; Paulson, A.L.; Suk, H.-J.; Abdurrob, F.; Drummond, G.T.; Guan, W.; Young, J.Z.; Kim, D.N.-W.; Kritskiy, O.; Barker, S.J.; et al. Multi-Sensory Gamma Stimulation Ameliorates Alzheimer's-Associated Pathology and Improves Cognition. Cell 2019, 177, 256-271.e22. [CrossRef] [PubMed]

88. Clements-Cortes, A.; Ahonen, H.; Evans, M.; Freedman, M.; Bartel, L. Short-Term Effects of Rhythmic Sensory Stimulation in Alzheimer's Disease: An Exploratory Pilot Study. JAD 2016, 52, 651-660. [CrossRef]

89. Adaikkan, C.; Middleton, S.J.; Marco, A.; Pao, P.-C.; Mathys, H.; Kim, D.N.-W.; Gao, F.; Young, J.Z.; Suk, H.-J.; Boyden, E.S.; et al. Gamma Entrainment Binds Higher-Order Brain Regions and Offers Neuroprotection. Neuron 2019, 102, 929-943.e8. [CrossRef] 